\section{The European Social Fund Supports the Reintegration of the Long-term Unemployed Individuals Aged 50+ Into the Labor Market - A Comparison of the Federal States in Austria}

\section{Azra Kadri}

The European Social Fund, Vienna, Austria

kadri.azra.09@gmail.com

\section{Vito Bobek}

University of Maribor, Faculty of Economics and Business, Slovenia vito.bobek@um.si

\section{Tatjana Horvat}

University of Primorska, Faculty of Management, Slovenia tatjana.horvat@fm-kp.si

\begin{abstract}
This paper shows the importance of European Social Fund's (ESF) countermeasures for reintegrating long-term unemployed persons aged $50+$ in Austria since their number has increased in recent years. Four research questions are defined, which deal with the theoretical background, the ESF's contribution, the possible causes of long-term unemployment, and their reflection in a country comparison figures. For the qualitative methodology, we conducted expert interviews and case study analysis. Concerning the quantitative method, we evaluated raw data from the AMS Public Employment Service, Austria, and Statistics, Austria. A correlation was established based on the content-related evaluation of the theoretical approaches, the expert analysis, and the presentation of statistics. It is necessary to identify the causes in time and take appropriate measures to prevent them from combating longterm unemployment among this target group.
\end{abstract}

Keywords: labor market, long-term unemployed aged 50+, the European Social Fund, Austria

\section{Introduction}

The increasing age of the population is noticeable in the European context and Austrian society. In recent years, the baby boomer generation of the 1960s has grown into the 50+ age group. As a result, the proportion of the population of working age between 50 and 64 has increased. In Austria, the number of unemployed people aged 50+ has been growing faster than in the other groups since November 2009. Over a more extended period, from February 2000 to February 2019, the number
REVIEW PAPER

RECEIVED: OCTOBER 2020

REVISED: APRIL 2021

ACCEPTED: MAY 2021

DOI: 10.2478/ngoe-2021-0012

UDK: $339.96: 331.56(436)$

JEL: J64

Citation: Kadri, A., Bobek, V., \& Horvat, T. (2021). The European Social Fund Supports the Reintegration of the Long-term Unemployed Individuals Aged 50+ Into the Labor Market - A Comparison of the Federal States in Austria. Naše gospodarstvo/Our Economy, 67(2), 49-65. DOI: 10.2478/ ngoe-2021-0012

\section{NG OE}

NAŠE GOSPODARSTVO OUR ECONOMY

\section{Vol. 67 No. $2 \quad 2021$}

рp. $49-65$ 
of people aged 50+, registered as unemployed, has almost doubled. This issue will remain critical in the future because the long-term trend towards an older working-age population will continue in the coming years (Arbeitsmarktservice Oesterreich, 2020; European Parliament, 2021).

From the existing theory and empirical research, we know that since the end of 2009, the number of unemployed persons aged 50+ has increased disproportionately compared to the other age groups in developed countries. It is relatively complex for people aged 50+ to return to the labor market after losing their jobs. This situation reflects in a more extended period of unemployment. A stay in unemployment of more than 365 days represents long-term unemployment, making it even more challenging to return to work. Among the factors perceived as particularly burdensome for older people are the increasing density of the workload, low management culture, devaluation of knowledge due to rapid technological change, and the growing burden of stress and time pressure. Three groups of risk factors are distinguished. Firstly, the high physical work requirements, the stressful and dangerous working environment, and poorly organized work. There is a clear link between long-term unemployment and characteristics of the unemployed persons, e. g. lower qualifications, and health restrictions (Clemens 2001, 23 - 28; Westermeier 2019, 6).

The research gap exists in terms of how the ESF, via respective national authorities, could integrate the long-term unemployed into the labor market. In general, the ESF aims to increase employment opportunities, invest in education, skills, and lifelong learning, and actively involve people at risk of poverty and exclusion. Therefore, the ESF has a higher budget and a specific list of priorities to reduce unemployment, both for categories of people at risk of poverty and people excluded from society (Artis \& Nixson 2003, 256 - 259). Unemployed people are the leading cause of poverty and social exclusion (Council of Europe, 2010). The European Social Charter (ESC) refers to social and economic human rights in Articles 1, 4, 15, and 30. In addition to the right to work and adequate remuneration, ESC also defines disabled people's rights to independence, integration, and participation in society. Regardless of their age and the origin of their disability, to take the necessary measures for people with disabilities, it is required to provide them with access to public or private institutions, counseling, education, vocational training, and employment. More specifically, Article 30 defines the right to protection against poverty and social exclusion. Appropriate measures are necessary to promote engagement, housing, training, education, culture, and social and medical assistance for individuals and their families, living in social exclusion or poverty situations. If these measures need to be adapted, it is also necessary to implement them (Council of Europe, 1996).
Apart from the national support measures for the reintegration of the long-term unemployed people aged 50+ into the labor market, the ESF intervenes to avoid the consequences of long-term unemployment and to ensure stability (Mathijsen 2010, 399). The issue of long-term unemployment and its causes, factors, and effects is an important topic not only in the Austrian but also in the European context.

This paper aims to illustrate the importance and relevance of national support measures for reintegrating the long-term unemployed people aged 50+ into the labor market. It also aims to explain these measures from the organization's point of view, the so-called funding recipient. Following the qualitative and quantitative analyses, the empirical results are evaluated and documented. Apart from the primary research questions, the paper also highlights the sustainability of ESF projects and possible improvement potentials for the next ESF+ funding period. Finally, it draws conclusions and provides an outlook for the next ESF+ funding period.

The main research question is "What are the measures with which the ESF, via respective national authorities, could integrate the long-term unemployed people aged 50+ into the Austrian labor market?” The supplement research questions that combine theory and practice with facts, figures, and a case study are the following:

1. RQ1: What are the ESF principles, and how is the ESF procedure implemented in Austria? We base RQ1 on the literature arguing that the creation of European Social Fund (ESF) improved employment possibilities and contributed to raising the standard of living (El-Agraa 2011, 26). The EU's Common Provisions Regulation No. 1303/2013 of the European Parliament and the European Council contains the general provisions for the European Structural and Investment Funds (ESI Funds) 2014-2020. The provisions of this Regulation determine the requirements for the implementation of the funds. The Austrian Partnership Agreement links the EU framework and the national and regional programs of the four ESI funds. This partnership intends to ensure that the expenditure is as effective and efficient as possible and responds to the needs of the region or community concerned (ÖROK, 2019).

2. RQ2: What are the possible causes, factors, and effects concerning age unemployment? Discrimination in general, as well as in the workplace, can occur at different levels and take different forms, such as worse access to the labor market (employment discrimination), lower wages (wage discrimination), and reduced opportunities for further training (Putz et al. 2014, 18). Another aspect is discrimination in the workplace, which is manifested, among other things, 
by age-segmented task assignments and exclusion from certain more prestigious activities. In addition, we can also include a lack of career development opportunities or a lack of opportunities for further training (Putz et al. 2014, 67). The forms of discrimination mentioned here lead to reduced career opportunities in general, lower income from gainful employment, and fewer opportunities for individual development. Personal characteristics, such as age, also lead to differentiation in the labor market (Putz et al. 2014, 18).

3. RQ3: What contribution has the ESF made to the reintegration of thelong-term unemployed aged 50+ in Austria? One of the key objectives of the Europe 2020 strategy is to increase the employment rate, especially that of older workers, to $77 \%$ - 78\% by 2020 (Lutz \& Bock-Schappelwein 2014, 52). In the 2018 ESF Annual Implementation Report, among several other aspects, concerning progress in implementing measures to address the unique needs of the target groups most at risk of poverty, discrimination, or social exclusion, with a particular focus on marginalized communities and people with disabilities and the long-term unemployed are stated (ESF Austria, 2019).

4. RQ4: How did the long-term unemployment rates of the people aged 50+ develop between 2004 and 2019 in the Austrian regions, and which demographic characteristics are relevant? As recorded by the AMS, long-term unemployment was a negligible indicator in Austria until a few years ago. However, it has increased significantly since the AMS changed its strategy in 2014, which led to fewer but longer-lasting measures. Therefore, the numbers have increased significantly from 2014 (Arbeitplus.at, 2020).

This paper is divided into several units and covers the ESF's theoretical aspects and the fundamentals of long-term unemployment. On the one hand, the focus is on theories; on the other hand, statistics and qualitative interviews support it. In addition to research of textbooks, we also used relevant journals and internet sources to formulate the theoretical part of the paper.

\section{Theoretical Background}

\section{Factors of long-term unemployment}

According to AMS Austria definition, persons registered as unemployed for more than 365 days are considered long-term unemployed. These persons are not involved in education and are not entitled to training measures (NEET). Any interruptions of up to 28 days (e. g. short training, illness, or temporary employment episodes) do not change their status (Arbeitsmarktservice Österreich, 2020).

According to the Austrian Public Employment Service, demographic shifts and changes in labor market participation are essential explanatory factors for the disproportionate increase in unemployment among older people. As mentioned above, some demographic characteristics play a role, including age criteria. The working-age population in Austria has aged in recent years, mainly due to the baby boom generation in the 1960 s, with a high birth rate. The number of persons aged $50+$ has thus increased. Consequently, the share of the people aged 50 to 64 in the working-age population has grown over the years, and the forecasts also indicate a further increase. Apart from the population's age structure, the employment behavior of people aged 50+ has also changed in recent years. The critical point is that they retire early less frequently and thus remain longer in the labor market. As a result, more people in this age group might potentially be employed but are also unemployed. (Arbeitsmarktservice Österreich 2020a, 1).

Demographic factors include rising life expectancy, aging of the "baby-boom" generation, and a low birth rate. The birth rate in Austria is 1.4 children per woman, considerably below the minimum ideal value of 2.1. Furthermore, the fact that pregnant women's average age is continuing to rise significantly increases the generation gap (Gruber et al. 2007, 16).

Since the end of 2009, the number of unemployed persons aged 50+ has increased disproportionately compared to the other age groups. According to AMS statistics, the number of persons aged $50+$, registered as unemployed, has almost doubled from 2000 to 2019. About a quarter of them are 50 years old or older (Arbeitsmarktservice Österreich 2020, 2).

It is relatively difficult for people aged $50+$ to return to the labor market after losing their jobs, reflecting a more extended period of unemployment. A stay in unemployment of more than 365 days represents long-term unemployment, making it even more challenging to return to work. Almost 50 percent of the long-term unemployed people in September 2019 were 50 years old or older (Arbeitsmarktservice Österreich 2020, 3). However, it is difficult to get back into employment after becoming long-term unemployed (Klinger \& Rothe 2010, 632).

There are several factors mentioned by which older employees are more affected by possible unemployment. On the one hand, a higher risk of losing one's job implies changes in the company or restraints and prejudices towards older people. Often the structures in the companies are not 
age-appropriate, meaning that usually, after a certain age, no further training is offered, and thus no other career opportunities arise. An additional factor is the different levels of stress in the various occupational groups and sectors. Older people, particularly physical workers, are more affected if there is too little health promotion. These people then usually suffer from deteriorating health. Among the factors perceived as particularly burdensome for older people are the increasing density of the workload, low management culture, devaluation of knowledge due to rapid technological change, and the growing burden of stress and time pressure. Three groups of risk factors are distinguished. Firstly, the high physical work requirements, the stressful and dangerous working environment, and poorly organized work. There is a clear link between long-term unemployment and characteristics, lower qualifications, and health restrictions (Clemens 2001, 23-28; Westermeier 2019, 6).

In particular, the long-term unemployed confront the expectation of taking up gainful employment and overcoming their dependence on social benefits as soon as possible. Primarily, this same unemployed group is unlikely to cope with the new conditions of competition and competitiveness and will also have little chance of finding a job independently in the foreseeable future. Although it is assumed that this group is less likely to be distant from the labor market or to have a low willingness to work, health restrictions and a lack of education or training qualifications are more likely to be a reason for their long-term unemployment (Lobato 2017, 4).

Concerning the qualification of older workers, almost every fifth company considers that older applicants' qualifications and competence levels are insufficient (Putz et al. 2014, 59). Discrimination in general, as well as in the workplace, can occur at different levels and take various forms, such as worse access to the labor market (employment discrimination), lower wages (wage discrimination), and reduced opportunities for further training (Putz et al. 2014, 18). Another aspect is discrimination in the workplace, which is manifested, among other things, by segmented task assignments and exclusion from certain more prestigious activities. Besides, a lack of career development opportunities or a lack of opportunities for further training can also be included (Putz et al. 2014, 67). The forms of discrimination mentioned here lead to reduced career opportunities, lower income from gainful employment, and fewer individual development opportunities. Personal characteristics, such as age, also lead to differentiation in the labor market (Putz et al. 2014, 18).

The increase in poverty has been the concern of European policymakers since the mid-70s, leading to the first program to combat poverty. The concept of social exclusion is addressed in a political and legal context within the EU, whereby the Treaty of Amsterdam lists this issue as one of the six objectives of European social policy intending to combat exclusion (Barnes et al. 2002, 12-14).

\section{Age-related employment problems in companies}

Response to unemployment of disadvantaged groups of workers is becoming a topic of interest, especially in times of recession. Some sectors of the economy or companies may be affected more than others by cyclical economic ups and downs. For example, immigrants represent a disproportional share in economically sensitive sectors such as construction or the hotel and catering industry (Prean \& Mayr 2016, 1-18).

Furthermore, long-term unemployed persons develop feelings of guilt about their long-term unemployment and experience financial difficulties and lack of social contacts. In addition, this affected group of people suffer from a loss of confidence, feelings of isolation, and decreasing self-motivation (Patton \& Donohue 1998, 337).

\section{Measures to combat long-term unemployment}

First, conditions must be created to develop older people's potential, as they show experience in terms of knowledge, learning ability, and motivation (Clemens et al. 2005, 193). For years, efforts have been made in theory and practice to promote older and underperforming staff in the labor market. Already in the mid-nineties, various model experiments were undertaken. In general, five areas of measures were defined, including qualification measures, work design, parttime work for older employees, personnel development, and integration of more senior and severely disabled persons (Clemens 2001, 101-140).

The results of a study in Austria, which analyzed part-time schemes for older workers, are in line with international results on models for a smooth transition from employment to retirement. These programs often provide an alternative form of transition to retirement. The entry age for partial retirement should be based on the statutory retirement age to extend working life (Graf et al. 2011, 228).

Qualification measures for older workers and older long-term unemployed are of utmost importance. Older workers' qualifications must be integrated into a system of organizational and personnel development and innovative career design. Implementation projects have proven that scientific models in the field of competence development work in practice. Work design means adapting the workload structure of a job to the performance of the integrated person. Measures must be taken to ensure that the workload is reduced. The work 
activity is designed to refer to ergonomic and technical adjustments, reduce time pressure and inappropriate working hours, and assure a health-friendly performance of work. Since the 1970 s, the concepts have been developed To ensure a smooth transition to retirement. This method of reducing working hours intends to enable a slow transition to later retirement. Through personnel development and career planning, older employees with health problems are to be integrated. The basic idea here is to enable promotion and career opportunities and thus create a less stressful workplace.

Furthermore, acquiring new qualifications and thus experiencing a positive professional change is another positive aspect. The last measure integrates older and severely handicapped people into new rationalization concepts, such as group work. Older people can use their skills and capabilities through teamwork (Clemens 2001, 101-140).

Age should not be used as a selection criterion. Instead, the focus must be on age-appropriate learning, primary education, good healthcare, fair wage, and human resources policies. Finally, it should be mentioned that the most critical factor is the mental attitude towards aging. It is up to companies and politicians to promote an appropriate and more positive mindset regarding aging (Von Cranach et al. 2004, 223-227).

One of the key objectives of Europe 2020 strategy was to increase the employment rate, especially that of older workers, to approx. 78\% by 2020 (Lutz \& Bock-Schappelwein 2014, 52). In international comparisons, the low employment rate of older people and relatively high social protection expenditure on pensions are seen as a critical weakness of Austria. One factor here is the health situation. The overall strategy to promote work and employability consists of prevention and treatment, activation and reintegration, and protection. The area of activation and reintegration was identified as underdeveloped in Austria. Against the background of demographic changes, the issue of active and healthy aging is particularly relevant (ESF Austria 2019, 108).

One example mentioned for Austria is individual socio-economic enterprises (SÖB), which are not profit-oriented social enterprises. They offer temporary jobs, so-called transit jobs for the long-term unemployed. Thereby employment is combined with training and continuous support to overcome possible problems. The long-term unemployed are allocated to the various companies by the public employment services. These projects are also supported and partly financed by the ESF (European Commission 2019, 32-33).

In the 2018 Annual Implementation Report (AIR), subsequent information was provided, among several other aspects, concerning progress in implementing measures to address the unique needs of the target groups most at risk of poverty, discrimination, or social exclusion, with a particular focus on marginalized communities and people with disabilities and on the long-term unemployed. From call documents analysis, IP 2.1 covers a wide range of target groups strongly affected by poverty, discrimination, or social exclusion. Most of the calls (18) are directed at "persons with a migration background, followed by the case of "BMS (Means-tested Minimum Income) recipients with multiple problems" (13 calls) and "persons with no or insufficient employment integration or persons who are far from the labor market and have low employability" (12 calls). Further mentions are "Educationally disadvantaged and low-qualified persons" (10 calls), "People with disadvantages, impairments or disabilities" (10 calls), or "Other marginalized groups with low employability and workability" (9 calls). Far less common are "working poor" (3 calls), "Roma/Romnja" (1 call), and "addicts (focus: alcohol addiction)" (1 call) addressed in the calls. However, it can be assumed that these groups are to be found, for example, as participants in projects of the calls for "persons with a migration background who are remote from the labor market" or "BMS recipients with multiple problems" and so forth (ESF Austria 2019, 128).

\section{Methodology}

We used quantitative and qualitative methods to answer the research questions in this paper. Statistical data on long-term unemployment of persons aged 50+ from Austria and its provinces are presented and compared. Besides, interviews are conducted with ESF funding organizations, the AMS Public Employment Service Austria, and a funding recipient is used as a case study. The ESF funding bodies provide information, advice, support, and guidance for the various project submissions and are thus an essential component in the implementation of the ESF in Austria. As the national platform for labor market policy, the AMS combines facts and figures with direct access to the long-term unemployed persons aged 50+ and contributes an essential part to this research with its empirical data. The direct cooperation with the actors concerned enables the project organizers to access the data collection of relevant information to provide individual support to the project participants. The long-term unemployed persons aged 50+ are prepared for the labor market through various measures. The concepts and the reports of the project executing organizations provide data for future projects and are also important indicators for the EU Commission. Following the qualitative and quantitative analysis, the empirical results are evaluated and documented. In addition to the main questions, we highlight the sustainability of ESF projects and possible improvement potentials for the next ESF+ funding period. Finally, the topic is briefly 
summarised, a conclusion is drawn, and an outlook on the next ESF+ funding period is framed.

For the theoretical part of the work, in a first step, secondary literature was studied to define the relevant key terms. This information was obtained by searching books, relevant scientific articles, and journals online and printed. In the second step, the research questions RQ1, RQ2, and RQ3 were answered based on empirical studies in the form of qualitative expert interviews with the responsible authorities in the federal states and the administrative authority. Based on the results of the initial literature search and the qualitative research, a quantitative-methodological approach is applied to answer the research question RQ4, using unique quantitative evaluations of the data sets of the Austrian Public Employment Service, as well as evaluations from the paid database of the Statistics Austria and the corresponding reports.

We conducted the interviews according to a structured interview guide. Four personal interviews took place in the experts' offices in Salzburg. The advantage of individual interviews is the more precise data collection and the fact that personal communication provides an opportunity to ask sub-questions and perform in-depth research. However, since the experts from the other federal states and institutions were not represented due to the worldwide pandemic situation COVID -19, the interview questionnaires were sent out in a written form by e-mails. The detailed answers of the experts were subject to an in-depth analysis. We clarified the ambiguities by subsequent telephone conversation.

\section{Selection of the interviewed persons}

The theoretical aspects must first be considered to select suitable persons for interviews. It is essential to ask who the experts are and how they are defined. According to Kaiser $(2014,36)$ an expert has "special knowledge" while a non-expert has only general or everyday knowledge. The experts, who have already been involved in implementing the ESF program for several years, were selected for this study. The people responsible for this area at the national and federal levels were chosen carefully. Figure 1 shows the selected experts for the interviews in this research.

The interview guide is structured into five main parts, which are divided into sub-categories. These are shown in figure 2.

All interviews are transcribed and analyzed in German to follow Kuckartz's (2010) transcription rules and not show any falsification of the interview experts' statements. Only the results of the content analysis are translated into English.

For the evaluation of the expert interviews, a method, which leads to the collection of results utilizing a step-by-step procedure, was chosen. The basic principle of the content analysis of a summary is that the resume's respective abstraction level is precisely defined. According to Mayring (2015, 72), content analysis is divided into the following four steps.

There is, among other possibilities, the possibility of using computer programs to carry out a qualitative content analysis of the interviews. The MAXQDA program was chosen for this analysis because we conducted interviews in German. This program is available in a German version, including a manual, and provides many practical examples in German (Kuckartz, 2010, 8). Furthermore, this program offers not only free webinars but also a test version. Specifically, the program MAXQDA Plus was chosen because it contains the module "MAXDictio" in addition to the functions of MAXQDA Standard. This module enables the implementation of numerous quantitative text analysis procedures, especially in qualitatively oriented projects. There are also tools for visual text exploration, performing vocabulary analysis, supporting content analysis, and operationalizing dictionaries with which groups of self-defined words can be created and evaluated (MAXQDA - Products, 2020). One of the core functions of MAXQDA, which plays a vital role in content analysis, is the coding of the text content of interviews. Coding is assigning one or more codes to such a segment, enabling a systematic qualitative content analysis. The selection of codes is an instrument for identifying and classifying content and creating order (MAXQDA - About Codes and Coding, 2020).

The code system chosen for the qualitative evaluation of the interviews is based on the interview guide's categories. The focus was divided into five main parts, which were then divided into sub-categories. On this basis, a code system was developed in the software that can code the relevant text passages so that the analysis steps, according to Mayring (2015), can then be carried out in a logical sequence (figure 4). 
Figure 1. Introduction of the selected experts for interviews

\begin{tabular}{c} 
EXPERT INTR \\
\hline $\mathrm{P} 1$ \\
\hline
\end{tabular}

Expert P1 is a member of the social inclusion and social welfare department and is responsible for the needs-based minimum benefit system and the basic provision of some individual support measures. Besides, P1 has been working with the ESF since the 1990s and is responsible for it.

[Interview 1_Institution1_P1: (Line 15 - 19)]

$$
\text { P2 }
$$

Expert P2 is a qualified social work specialist and has been active for three years in the field of minimum income support and disability assistance.

[Interview 2_Institution2_P2_P3: (Line 13 - 17)]

\section{P3}

Expert $\mathrm{P} 3$ is head of the Social Affairs group and is active since 2003 in the areas of social welfare and disability assistance, and recently in the fields of minimum income and participation. In addition, the scope of responsibilities also includes labour market projects.

[Interview 3_Institution3_P4: (Line 12 - 18)]

$$
\text { P4 }
$$

Expert P4 is head of the research department in the fields of labour market analysis and statistics. Furthermore responsible for controlling and a part of public relations.

[Interview 3_Institution3_P4: (Line 12 - 18)]

\section{P5}

Expert P5 has been working for Caritas for seven years in the area of perspectives and commitment. This area includes employment, sustainability as well as migration and opportunity. In addition, there are the areas of responsibility, living standards and assistance to the homeless as well as civil society initiatives.
C1

\begin{tabular}{l} 
P6 \\
Expert P6 covers the areas of the labour market, the \\
promotion of apprenticeship training and the promotion of \\
scientific institutions. The labour market sector comprises \\
the development and implementation of the country's \\
labour market and qualification strategy as well as the \\
implementation of the partnership principle within the \\
framework of the "Territorial Employment Pact". In addition, \\
the area of responsibility includes the implementation \\
of the ESF programme (investment priority 2) of the \\
Operational Programme. \\
[Interview 5_Institution4_P6: (Line 15 - 20)] \\
\hline P7
\end{tabular}

Expert P7 is responsible for the European Social Fund (ESF) in the Economics and Research Division / Labour Market Department. In addition, P7 is also responsible for national funding projects in the youth sector.

[Interview 6_Institution5_P7: (Line 15 - 15)]

\section{P8}

Expert P8 has a management position in the ESF Minorities funding area.

[Interview 9_Institution8_P10: (Line 15 - 19)]

$$
\text { P10 }
$$

Expert P10 is responsible for the ESF in the department of general economic affairs. The tasks include the processing of EU programmes (ERDF and ESF) as well as the development of topics for calls and the operational implementation.

[Interview 9_Institution8_P10: (Line 15 - 19)]

\section{P11}

Expert P11 is a representative of the ESF Managing Authority in Austria and responsible for public relations and communication. In addition, the scope of responsibilities includes the thematic focus "Active and healthy ageing".

[Interview 4_CARMI_P5: (Line 14 - 25)]

[Interview 10_Institution9_P11: (Line 15 - 15)]

*Expert P9 is responsible for the target group of youth with impairments / disabilities and unfortunately does not fall within the focus of the master thesis. [Interview 8_Institution7_P9: (Line 9-11)]

Source: Own illustration

Figure 2. Interview guideline

$\begin{array}{ccc}\text { PART I } & \text { PART II } \\ \text { Introduction } & & \begin{array}{c}\text { Long-term } \\ \text { unemployment }\end{array}\end{array}$

\begin{tabular}{c}
\hline PART III \\
\hline Workflow of \\
ESF-Projects
\end{tabular}

$\frac{\text { PART IV }}{\text { Contribution }}$

\begin{tabular}{c}
\hline PART V \\
\hline ESF+ \\
\hline
\end{tabular}

Source: Own illustration 
Figure 3. Workflow of the summary content analysis

I. Paraphrasing

- Delete all text elements that have no (or little) content, such as embellishing, repetitive, illustrative phrases.

- Translation of text passages with content to a uniform language level.

- Transform them into a grammatical short form.

\section{First Reduction}

- Delete synonymous paraphrases within the evaluation units.

- Delete paraphrases that are not considered essential to the content at the new level of abstraction.

- Adoption of the paraphrases that are still considered central to the content (selection).

- Take theoretical assumptions for cases of doubt.

Source: Own illustration based on Mayring 2015, 72

Figure 4. MAXQDA - Code system Qualitative Analysis

\begin{tabular}{|c|c|c|}
\hline \multicolumn{3}{|r|}{ CODE SYSTEM } \\
\hline O & \multirow{3}{*}{ C1 } & Expert Introduction \\
\hline$\bullet$ & & Expertise at national level \\
\hline$\bullet$ & & Expert knowledge of ESF \\
\hline O & \multirow{3}{*}{$\mathrm{C} 2$} & Long-term unemployment \\
\hline$\bullet$ & & Causes and Factors \\
\hline$\bullet$ & & Correlation of demografic characteristics \\
\hline O & \multirow{3}{*}{ C3 } & Workflow of ESF-Projects \\
\hline 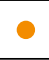 & & Call to Implementation \\
\hline$\bullet$ & & Monitoring and Evaluation \\
\hline O & \multirow{3}{*}{ C4 } & Contribution \\
\hline - & & ESF and national level \\
\hline$\bullet$ & & Co-operation with AMS Austria \\
\hline 0 & \multirow{3}{*}{ C5 } & ESF+ \\
\hline$\bullet$ & & Publications \\
\hline - & & Potential for improvement \\
\hline
\end{tabular}

Source: Own illustration
II. Generalization to the level of abstraction

- Generalize the objects of the paraphrases to the defined level of abstraction, so that the old objects are implied in the newly formulated.

- $\quad$ Generalize the sentence statements (predicates) in the same way.

- Leave the paraphrases that are above the desired level of abstraction In case of doubt, use theoretical assumptions.

\section{Second Reduction}

- $\quad$ Combining paraphrases with the same (similar) object and similar statement to form a paraphrase (bundling).

- $\quad$ Combining paraphrases with several statements about one object (construction/integration).

- $\quad$ Combining paraphrases with the same (similar) object and different statements to form a paraphrase (construction/ integration).

- $\quad$ Take theoretical assumptions for cases of doubt.

\section{Results}

Based on the results, the main research question "What are the measures with which the ESF, via respective national authorities, could integrate the long-term unemployed persons in the age of 50+ into the labor market in Austria?” could be answered. The ESF Managing Authority has overall responsibility for the operational implementation of the European Social Fund. The implementation itself is decentralized via so-called administrative funding bodies in the federal states. These funding bodies allocate and manage the subsidies, depending on the thematic focus. The corresponding calls and awards are recorded in a central database (ZWIMOS) and published on the ESF website. This database is an essential tool explicitly developed for ESF implementation and the management and control of all projects and their indicators. The funding bodies can create calls in this database, which are then published on the website by the managing authority. Before the calls are prepared, ideas are collected, and a call paper is developed. Afterward, interested project executing organizations can inform themselves and submit their project idea in cooperation with the funding agency via ZWIMOS. After a successful application and a review of the submitted ideas and concepts, the agency will conclude a funding contract with the most competitive project management organization. In the contract, the rights and obligations of recipients are regulated, and the payment modalities are defined to start the 
project implementation. In general, projects are financed 50\% nationally and $50 \%$ by the ESF. Applicants who do not meet the admission criteria will be rejected. After the project starts, the project organizers must comply with the rights and obligations as agreed in the contract, including complete documentation of the project's progress and the project participants by submitting factual reports and a final report. These reports ensure the traceability of the project implementation and the measurability of the specified measures and objectives. It is also essential that all relevant documents are uploaded into the system to ensure transparency for further reviews by the audit authorities during on-site inspections and system audits. An essential element is to ensure practical cooperation and communication between the parties involved to achieve a sustainable impact. The funding agency continuously reviews the projects and the First Level Control (FLC) to meet their defined objectives. This can take the form of interim or final settlements. The FLC checks the expenditure submitted for settlement for eligibility following the prescribed manuals and particular guidelines. Only after several reviews and checks will the final funding amount be transferred to the project owner. After that, projects are subject to a second check by the Second Level Control (SLC) based on samples. There are also additional controls at higher levels of authority. One of these is the project examination, which is carried out on a sample basis. Another is the system audit, which examines the managing authority and the responsible bodies to determine whether the entire ESF implementation process complies with the management and control system (VKS).

\section{Answering RQ1: What are the ESF principles, and how is the ESF procedure implemented in Austria?}

In addition to the theoretical research, the ESF managing authority, those responsible for the managing bodies, and a project promoter were interviewed using the interview method to answer this first research question.

The funding organization and the FLC continuously review the projects to ensure that they achieve the defined objectives. This can take the form of interim or final accounts. The FLC checks the eligibility of the expenditure submitted for settlement according to the prescribed manuals and particular guidelines. Only after several checks and controls are carried out, the project owner's final amount of funding is transferred. After that, the projects are subject to a second audit by the SLC based on random samples. There are also additional controls at higher levels of authority. One of these is the project audit, which is carried out on a sample basis. Another is the system audit, where the managing authority and the responsible bodies are examined to ensure that the entire ESF implementation process aligns with the management and control system (VKS).

\section{Answering RQ2: What are possible causes, factors, and effects related to age unemployment?}

In addition to theoretical research, the second research question was answered by interviewing the Public Employment Service and the responsible persons of the implementing organizations and a project executing agency.

The results of the content analysis show many similarities and overlaps compared to the theoretical approaches. In summary, it was found that both long-term unemployment and unemployment, in general, have several causes. One of them is economic development, which is of crucial importance. Unforeseen events, such as financial crises, wars, and pandemics, can occur. Demographic characteristics play an essential role for all those who are unemployed. Another crucial aspect is the health situation of people in old age, which impacts performance. Physical performance is limited for people aged $50+$, especially in the construction industry. In principle, in addition to physical illnesses, mental illnesses also play a significant role, as, over the years, excessive pressure has arisen in both professional and private life. Discrimination or multiple discrimination based on origin, gender, and language is often the reason for a difficult start in the labor market. Minorities are often affected and must struggle with traditional role models instead.

Besides, it must be considered that older minorities are more often affected by diseases and lower life expectancy. Another important aspect is the outdated qualifications. A lack of further training opportunities and insufficient investment in qualification and cooperation programs is a significant factor that leads to stagnation in the capabilities of those affected. In summary, the theoretical findings and quantitative and qualitative analyses show that older and low-skilled persons are affected by long-term unemployment much more frequently than younger or higher qualified unemployed persons. However, it is noticeable that people with an apprenticeship certificate are also more regularly affected by unemployment. In many cases, this is probably because these people have not exercised their acquired qualifications over a long period, or their occupational profiles are outdated or no longer exist.

Moreover, it is noticeable that the choice of vacancies on the labor market for poorly or unskilled people is becoming smaller and smaller. Among the demographic characteristics, regionality plays an important role. It is more favorable to find a job in urban areas since they are easily accessible by public transport than the mountainous or rural areas. Finally, the question of the duration of unemployment is of utmost importance. Long-term unemployment has negative dynamics since the longer it lasts, the more difficult it is to find a way back into the labor market. 
Furthermore, personal risk factors, such as tense self-image and limited self-esteem, should not be underestimated. These individual risk factors endanger both economic existence and psychological well-being. Low esteem and hardly any perception and consideration of the employer or society's abilities lead to feelings of uselessness, fear, and despair. Besides, there exist various prejudices towards the people concerned, such as "Older people are too slow, cost too much money and perform less well, retire soon, are on sick leave more often or cannot cope with the digital and fast-moving world." However, the willingness to be mobile and flexible decreases with age - compared to younger workers, especially in the construction and tourism industries.

The underestimated issue is the biased image of this group of people, often stigmatized and classified as unfit or unwilling to work. It is often overlooked that older people also have more experience. There is a lack of perception and understanding that there is a very high outflow of know-how when people leave this age group, and thus the transfer of knowledge is lost for future generations. Under certain circumstances, a large part of the experience is put at risk. Although this cannot be demonstrated in payroll accounting, it can undoubtedly be seen in companies' performance.

\section{Answering RQ3: What contribution has the ESF made to the reintegration of the long-term unemployed people aged 50+ in Austria?}

The EU recommendations and the other measures were examined from the Austrian perspective to address this research question.

The case study was chosen because the target group is the same as the long-term unemployed people aged $50+$, and because it is a new project and the persons responsible for project implementation have no experience of the ESF. This is relevant because new project initiators have a unique perspective on the submission and implementation process. This case study provides different ideas from different perspectives. Finally, the sustainability of ESF projects is discussed. The ESF Managing Authority has provided a list of projects for the 2014-2020 funding period (ESF 2020, 2019, 2017a), downloaded as an Excel file from the ESF website. The list of projects applied in this document is dated January 31, 2020. This project list contains 1,129 projects from the beginning of the publication date in January 2014 to January 2020.

Concerning the target group defined in this paper, the longterm unemployed people aged $50+$, it can be noted that this group occurs in many projects. However, there are no specifically defined calls for proposals. The results of the EU recommendations show that three critical key results have already been achieved in Austria. These include developing a new profiling system in the Public Employment Services, a well-established one-stop shop, and close cooperation between employers Public Employment Services and employers. Nevertheless, there are still challenges that Austria must face.

On the one hand, there is still a gap between employers' qualification requirements and the long-term unemployed qualifications. On the other hand, data exchange between Public Employment Services and social services could be further improved. Finally, a specific, individual assessment of the long-term unemployed people needs to be carried out.

Besides the background of demographic change, the area of active and healthy aging is particularly relevant. In Austria, many social non-profit enterprises offer temporary jobs, so-called transit jobs, for the long-term unemployed in cooperation with ESF projects. These combine employment with training and continuous support to overcome possible difficulties.

The long-term unemployed are distributed by the Public Employment Services among different enterprises. The ESF Austria submits annual implementation reports and the corresponding information for citizens. According to the 2018 report, the target group most at risk of poverty, discrimination, or social exclusion was targeted. Furthermore, special attention was paid to marginalized communities, people with disabilities, and the long-term unemployed. By the end of 2018, a total of around 170,000 participants reached the ESF-funded measures.

Many demands have been made in migrants far from the labor market and needs-based minimum income recipients with multiple disabilities. The other calls concerned people with insufficient occupational integration or people far from the labor market and low employability. People with educational disadvantages and low qualifications and people with disabilities, impairments, or handicaps were also considered. Far less frequent were calls among the working poor and Roma/Romnja minorities and alcohol addicts.

Approximately $60 \%$ of the budget for the financing period 2014-2020 was approved for implementing projects until the end of 2018. This means that a program budget of around $40 \%$ is still available for further projects. As mentioned in the delimitation, this work cannot cover all ESF projects from the project list. Only one case study per federal state was listed, in which the target group of long-term unemployed people aged 50+ could have participated.

The Caritas case study presented, called CARMI, enables the gradual development of employability of minimum income 
recipients in the age of 50+ by providing employment, day structure, qualification, individual care, placement, and, if necessary, treatment. After clarifying the employability, Caritas offers a wide range of low-threshold and integrative employment opportunities to the people assigned in the city of Salzburg. Caritas Salzburg has extensive expertise in the implementation of projects for the labor market integration of older people. The planned measures, methods, and care settings provide personal stabilization and a gradual build-up of employability. Employment opportunities are in logistics, administration, sales, and crafts within the framework of a phased plan. Besides, it is intended to organize internships in the regular labor market if the applicant is suitable.

Concerning the intended placement in the regular labor market at the end of the project, various workshops and application training courses offer an ideal supplement. The maximum duration of the project participation is one year plus follow-up support. According to the ex-ante evaluation and the progress report on the partnership agreement, however, the ESF is not directly involved in sustainable development since no environmentally relevant investment measures are planned in the Operational Programme. In summary, the results conclude that, in addition to national measures, the ESF makes an essential contribution to the reintegration of long-term unemployed people aged 50+.

\section{Answering RQ4: How did the long-term unemployment rates of people aged $50+$ in the Austrian federal states develop between 2004 and 2019, and which demographic characteristics were significant?}

In this section, the research question RQ4 is answered with quantitative evaluations of the Austrian Public Employment Service data sets and related reports. These data were provided by the AMS exclusively for this research. Additional data were obtained from the database, for which a fee was charged by Statistik Austria. An overview of Austria, in general, is given in the subchapter. Subsequently, the figures of the federal provinces are presented.

\section{Long-term unemployment in Austria}

For a better overview, this chapter will highlight critical data in Austria to show the ratio of all unemployed individuals to long-term unemployed people aged 50+. Long-term unemployment has increased significantly since the change in Strategy of the AMS in 2014, which led to fewer but longer-lasting measures. Therefore, the figures from 2014 (Arbeitplus.at, 2020) have increased significantly.
All age groups have increased in size over the years. The total number of people in employment has more than doubled in the period 2004-2019. It is striking that the increase was considerable in the middle age group of 55 - 64. This shows that there are more and more older workers in the labor market and reflects the demographic structural development of the population.

From the Austrian point of view, the number of long-term unemployed people in the 50 - 54 age group has slightly decreased, while the number of long-term unemployed individuals in the 55 - 59 age group has remained unchanged. The number of long-term unemployed people aged 60+ has risen somewhat.

In table 1, the long-term unemployment within the employment measures is presented for 2004-2019 to illustrate the difference with the long-term unemployed (NEETS).

According to the figures in table 1, the total number of longterm unemployed people tripled between 2004 - 2019. The age group of 55 - 59 is most affected, followed by 50 - 54 years old.

The ESF has also introduced demographic indicators as a benchmark for project performance. Personal characteristics of the long-term unemployed persons aged 50+ indicate that the men are more affected than the women. Another significant difference concerns nationality. Natives are more affected by long-term unemployment than foreign nationals. The level of education is of great importance. Therefore, the lower the educational level, the higher the risk of drifting into long-term unemployment. People with primary education and those who have completed an apprenticeship are most often affected. After all, about half of them suffer from health restrictions.

\section{Comparison of the Austrian federal states}

The long-term unemployed are now examined in more detail and differentiated by region and other demographic criteria in table 2.

Table 2 provides an overview of the average number of long-term unemployed persons aged 50+ in Austrian federal states in 2004 - 2019. The results show that the provinces of Carinthia, Upper Austria, and Tyrol have recorded a massive increase. Comparing the last two years, 2018 and 2019, the numbers have increased by almost nine percent. Nevertheless, in 2019 Vienna also has the highest number of longterm unemployed persons in this age group. 
In Burgenland, the number of unemployed persons in this age group has decreased from 2004 to 2014. From 2014, however, long-term unemployment of this group of people has risen significantly, and by 2017 the number has almost quadrupled. In 2018 it fell slightly and rose very moderately in 2019. In Carinthia, this number almost tripled between 2004 and 2014. In 2014-2017, the number of long-term unemployed persons in this age group has more than doubled. In this federal state, this number has increased by $8 \%$ in the annual comparison of the period 2018-2019.

In Lower Austria, the long-term unemployment of people aged 50+ was low in 2004-2014. In the years from 2015 to 2017, this number more than doubled, while from 2018 onwards, it has slightly decreased. Apart from Vienna, Lower Austria is also the most affected region by long-term unemployment of people aged 50+. Upper Austria's longterm unemployment among the people in the age group 50+ was deficient from 2004 to 2014. In the years 2015-2017, the number of these people increased by more than eight times. On the contrary, this number has fallen slightly again from 2018 onwards.

Federal state Salzburg experienced a similar trend from 2004 to 2014, followed by a significant increase in the years 2014 to 2019, when the values have almost quadrupled. A comparison of the last two observed years (2018 and 2019) shows that this number has increased minimally. However, federal state Salzburg has the lowest number of long-term unemployed people aged 50+ after federal states Vorarlberg and Tyrol.

The decrease and increase of long-term unemployed persons in this age group can also be observed in Styria. Long-term unemployment in this federal state increased almost fivefold from 2014 to 2017. However, this number has slightly decreased from 2018 onwards.

In Tyrol, the number of long-term unemployed persons quadrupled in the period from 2004 to 2014. In the period from 2014 to 2017, this number has hardly doubled. It is remarkable in this federal state that the number of long-term unemployed persons in the age group of 50+ has decreased significantly from 2018 onwards.

Contrary to the trend in Vorarlberg, the number of longterm unemployed in the years 2004-2006, 2009, and 2010 is higher than in 2014. However, in the years 2014-2017, the number has almost tripled. In the comparison of the last two years, 2018-2019, the number has decreased minimally.

In Vienna, long-term unemployment of people aged 50+ fall rapidly from 2004 to 2005 and was very low in the period

Table 1. Long-term unemployed people in the context of employment measures for the individuals aged 50+ in Austria (annual average 2004 - 2019)

\begin{tabular}{|c|c|c|c|c|c|}
\hline Year & 50 to 54 years & 55 to 59 years & 60 to 64 years & 65 years and older & Total Sum (50+) \\
\hline 2004 & 6.272 & 6.772 & 2.760 & 137 & 15.941 \\
\hline 2005 & 5.702 & 5.226 & 2.163 & 122 & 13.212 \\
\hline 2006 & 5.554 & 4.803 & 1.632 & 118 & 12.107 \\
\hline 2007 & 5.190 & 4.361 & 1.489 & 115 & 11.155 \\
\hline 2008 & 4.763 & 4.072 & 1.615 & 112 & 10.562 \\
\hline 2009 & 4.908 & 3.891 & 1.542 & 99 & 10.439 \\
\hline 2010 & 6.078 & 4.267 & 1.493 & 93 & 11.931 \\
\hline 2011 & 6.267 & 4.551 & 1.762 & 92 & 12.672 \\
\hline 2012 & 6.623 & 5.147 & 2.104 & 84 & 13.958 \\
\hline 2013 & 8.379 & 6.938 & 2.553 & 91 & 17.960 \\
\hline 2014 & 13.021 & 12.218 & 3.993 & 113 & 29.345 \\
\hline 2015 & 16.714 & 16.826 & 5.621 & 140 & 39.300 \\
\hline 2016 & 17.937 & 19.257 & 6.796 & 165 & 44.155 \\
\hline 2017 & 17.815 & 21.284 & 7.961 & 181 & 47.241 \\
\hline 2018 & 15.104 & 20.461 & 8.258 & 221 & 44.045 \\
\hline 2019 & 14.354 & 20.748 & 8.814 & 279 & 44.194 \\
\hline
\end{tabular}

Source: Illustration of the own analysis based on specific AMS data 
Azra Kadri, Vito Bobek, Tatjana Horvat: The European Social Fund Supports the Reintegration of the Long-term Unemployed Individuals Aged 50+ Into the Labor Market - A Comparison of the Federal States in Austria

Table 2. Long-term unemployed persons aged 50+ in Austria (annual average 2004 - 2019, by federal states)

\begin{tabular}{|c|c|c|c|c|c|c|c|c|c|c|}
\hline Year & Burgenland & Carinthia & $\begin{array}{l}\text { Lower } \\
\text { Austria }\end{array}$ & $\begin{array}{l}\text { Upper } \\
\text { Austria }\end{array}$ & Salzburg & Styria & Tyrol & Vorarlberg & Vienna & Austria \\
\hline 2004 & 311 & 236 & 2.406 & 41 & 151 & 1.028 & 146 & 200 & 5.721 & 10.238 \\
\hline 2005 & 262 & 212 & 2.046 & 16 & 118 & 857 & 145 & 206 & 1.592 & 5.453 \\
\hline 2006 & 191 & 187 & 1.301 & 15 & 93 & 695 & 140 & 173 & 557 & 3.353 \\
\hline 2007 & 103 & 208 & 682 & 8 & 96 & 657 & 145 & 78 & 354 & 2.331 \\
\hline 2008 & 109 & 256 & 738 & 12 & 106 & 696 & 145 & 65 & 298 & 2.425 \\
\hline 2009 & 166 & 320 & 1.071 & 25 & 126 & 459 & 186 & 177 & 254 & 2.783 \\
\hline 2010 & 136 & 352 & 1.086 & 47 & 114 & 275 & 216 & 224 & 172 & 2.622 \\
\hline 2011 & 79 & 311 & 939 & 29 & 112 & 227 & 191 & 48 & 167 & 2.104 \\
\hline 2012 & 114 & 265 & 1.050 & 52 & 128 & 419 & 252 & 48 & 86 & 2.413 \\
\hline 2013 & 119 & 393 & 1.465 & 71 & 132 & 366 & 340 & 59 & 76 & 3.022 \\
\hline 2014 & 250 & 746 & 2.664 & 305 & 211 & 723 & 605 & 156 & 181 & 5.841 \\
\hline 2015 & 606 & 1.355 & 4.789 & 1.390 & 435 & 2.010 & 945 & 350 & 3.336 & 15.216 \\
\hline 2016 & 907 & 1.699 & 6.094 & 2.388 & 637 & 3.081 & 1.058 & 444 & 8.031 & 24.339 \\
\hline 2017 & 976 & 1.815 & 7.113 & 3.247 & 761 & 3.576 & 1.085 & 469 & 9.080 & 28.122 \\
\hline 2018 & 901 & 1.804 & 6.595 & 2.969 & 758 & 2.886 & 803 & 471 & 9.028 & 26.213 \\
\hline 2019 & 924 & 1.954 & 6.171 & 2.594 & 769 & 2.848 & 674 & 421 & 9.859 & 26.214 \\
\hline
\end{tabular}

Source: Illustration of the own analysis based on specific AMS data

from 2005-2014. On the contrary, the number has risen dramatically in the years from 2015 to 2019. A peak was recorded in 2019. Vienna is also the city most affected by long-term unemployment among the people in the age group $50+$.

Long-term unemployment of people in the age group 50+ has become significantly more critical in Austria from the middle of 2010. Previously, the share of long-term unemployed persons in the age group 50+ was low. The total number of employed persons more than doubled in the period from 2004 to 2019. As the theoretical conclusions in this research indicate, the figures also reflect demographic differences. The ESF also uses demographic indicators as a benchmark for project performance. The demographic graphs show significant differences in gender, age, nationality, education level, health status, and occupation. Besides, there is a correlation between qualifications and the occupations concerned. Unskilled workers or persons with apprenticeship training in administration, cleaning, trade, and construction are more affected by long-term unemployment. According to the data, the total number of long-term unemployed tripled in the period from 2004 to 2019. The age group of 55 to 59 years old is the most affected, followed by those aged from 50 to 54 .

Finally, figure 5 sorts the Austrian federal states according to the number of employed and long-term unemployed persons aged 50+ in the year 2019.

Figure 5. Comparison of Austrian federal states according to the number of employed and long-term unemployed persons aged $50+$

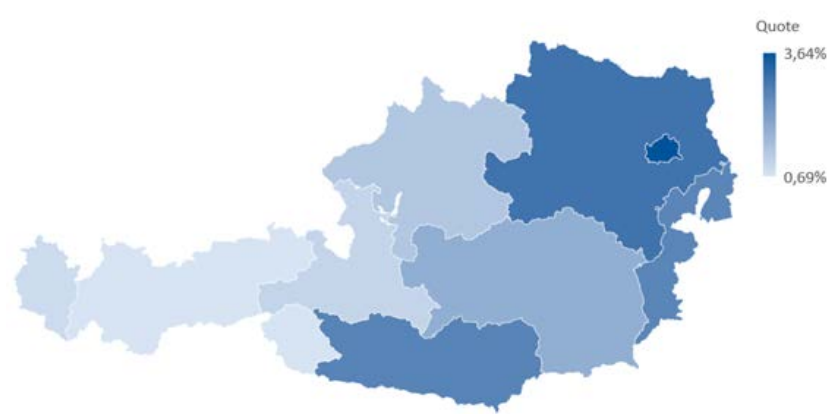

Source: Illustration of the own analysis based on specific AMS data

Figure 5 shows that regarding long-term unemployed persons aged 50+, the most affected federal states are Vienna, Lower Austria, Burgenland, and Carinthia. In the ESF+ for the following funding period 2021 - 2027, the possible potential for improvement was identified. The preparations for the ESF+ are proceeding according to plan. A continuous negotiation process is underway in the programming process. There is 
a close exchange with the European Commission and the funding bodies to prepare the ESF+ in the best possible way in terms of content and administration. Besides, preparations for the new Operational Programme ESF+ have begun. All information will therefore be published in detail on the ESF homepage. The following funding period's potential for improvement was identified and worked out based on the content analysis of questionnaires. Some considerations are summarised in the next section.

\section{Discussion}

\section{Contribution of the paper to the conceptual knowledge}

Within the theoretical part, the causes and factors of longterm unemployment were elaborated to understand the situation of the target group concerned. The individual risk factors were also covered. Finally, discrimination against older people in the labor market and poverty and social exclusion were addressed. The results of the content analysis, compared to the theoretical approaches, show many commonalities and overlaps.

In summary, it was found that long-term unemployment and unemployment, in general, have several causes. One of them is economic development, which is crucial. Unforeseen events can occur, such as economic crises, wars, and pandemics. Demographic characteristics play a significant role for all unemployed persons. Another decisive aspect is the health situation of older people, which impacts performance. Physical capacity is limited for people aged $50+$, particularly in the construction industry. In principle, in addition to physical illnesses, mental illnesses also play a significant role, as excessive pressure has occurred over the years in both professional and private life. Discrimination or multiple discrimination based on origin, gender and language are often the reasons for a difficult start in the labor market. Minorities are often affected and must struggle with traditional role models instead.

Furthermore, it must be considered that older minorities are more often affected by diseases and a lower life expectancy. A further significant aspect is the outdated qualifications. The lack of offers for further training and insufficient investment in qualification programs and cooperation programs is a significant factor that causes the qualifications of those concerned to remain stagnant. In summary, the theoretical knowledge and quantitative and qualitative analyses indicate that older and low-skilled persons are affected by long-term unemployment much more frequently than younger or higher qualified unemployed persons. However, it is noticeable that persons with an apprenticeship certificate are more frequently affected by unemployment. In many cases, this can probably be attributed to the fact that these persons have not exercised their acquired qualifications over a more extended period or that the occupational profiles are outdated or no longer exist. Moreover, it is noticeable that the selection of vacancies on the labor market for poorly or untrained people is becoming increasingly smaller.

\section{Contribution to the practice}

As a result, there is a clear need to streamline management and simplify ESF implementation. This need has been recognized at the European level and partly reflected in the new regulations' proposals. The requirements are rigorous in form and content and remain highly administrative, despite some improvements compared to previous periods. Smaller project promoters are often affected by these criteria. Although they have excellent ideas and experience in dealing with the unemployed and people at risk of poverty, they are excluded from the ESF outset. Because they have neither the necessary human nor technical resources, these bureaucratic requirements are a significant hurdle.

In summary, the following solutions were proposed to reduce the bureaucratic burden: simplifying audit manuals, formal criteria, guidelines, and the use of more straightforward and more understandable language. In addition to the bureaucracy, the time management of the submission phase was also addressed. The time between the call for proposals and submission, which is difficult for project initiators to manage in the ordinary course of business, is minimal. This point is very relevant for new applicants who have no experience with the ESF.

Another aspect is more intensive training and communication with management bodies. More intensive training of all those involved is essential when new, simplified accounting methods are introduced. As all audit manuals are published on the homepage, it would be a considerable simplification if there were access to audit checklists. It is assumed that the audit is conducted following these guidelines. In addition to the content implementation processes, the topics of the participants were also addressed. Key issues such as the reimbursement of travel expenses and, if necessary, psychotherapeutic and medical care are of great importance for the target group of the long-term unemployed in the age group of $50+$. As the theoretical approaches and the interviews have already indicated, this target group usually must cope with physical and psychological health consequences. Besides, regional differences generally make access to the project location more difficult, which involves travel costs. It would 
be useful for these calls to make special arrangements to pay travel costs and additional medical care.

Cooperation between the Laender was also addressed, but this project design issue needs to be discussed further. As far as the implementation of projects in ESF+ is concerned, the knowledge and experience already acquired will be applied and built on future economic developments. Future strategies must include new approaches, instruments, and measures that address the target groups of $50+$ and people with mental health problems. In this context, the pandemic COVID-19 will be crucial for the development of the Strategy, as this dramatic event has created many new challenges in terms of unemployment. Digitalization was also raised as an issue. More intensive use of digital media and databases will play an essential role in the future. The ESF+ aims to create further simplifications for all stakeholders and thus improve the image of the ESF. In the long term, ESF Austria plans to establish itself as a trademark of Europe's social dimension.

\section{Conclusion}

For the last 60 years, the ESF has been the EU's main financial instrument for investing in people, helping them find jobs, and creating fairer employment opportunities for all EU citizens. The ESF aims to improve employment and education opportunities and the situation of the most vulnerable people, such as those at risk of poverty. The Treaty of Rome had already laid the foundations, and the first funding programs were implemented in 1975.

The ESF had been part of the funding landscape since Austria's accession to European Union 25 years ago. Austria's primary focus is on promoting social integration, especially of disadvantaged groups and groups at risk of exclusion. For this reason, projects to prevent and combat unemployment, reduce school drop-out rates, and promote equal access to lifelong learning are supported. A budget of around 875 million euros was available for the labor market and qualification projects in the funding period 2014 - 2020. The ESF is co-financing about half of the costs of applicants with around EUR 442 million. The Operational Programme defined strategies for the Union's Strategy for smart, sustainable, and inclusive growth in economic, social, and territorial cohesion in 2014 - 2020.

Calls for proposals are published on the ESF website, based on the OP priorities and actions defined on the ESF website. The Managing Authority publishes all calls, regulations, and results and has overall responsibility for implementing and delivering the ESF program. Both the theoretical approaches and the analyses of the research questions show that, based on statistical data, it is essential to recognize the problem of long-term unemployment among the target group and identify the causes and take appropriate measures time. For this reason, targeted projects at the national level and ESF-funded projects are relevant for the reintegration of the long-term unemployed persons.

The results of the quantitative method show a substantial increase in long-term unemployment over the period from 2004 to 2019. In addition to the research questions, this paper gives a brief insight into the subsequent ESF+ funding period 2021 - 2027 and possible improvement potential. The results indicate that further simplifications in implementation are planned. Also, the European Commission proposes a total budget of 101 billion euros for the ESF+. Priority will be given to modernizing strategic infrastructure, strengthening human capital for competitiveness, improving working and living conditions, and environmental sustainability. The $\mathrm{ESF}+$ financial measures contribute to implementing the objective defined in Employment Guidelines, the European Semester overall objective of Policy Coordination smart, inclusive, and sustainable growth after 2020.

\section{Implications for future research}

Due to the global pandemic outbreak in early 2020, it appears that the group of long-term unemployed persons aged 50+ will increase dramatically. One reason for this will undoubtedly be the economic recession, with the tourism and accommodation sector being hit hard. Another point could be that the target group of the persons in the age of $50+$ will receive less attention than before, due to many unemployed and the budget will be used for other measures, such as short-time work. In the future, it will be challenging for this target group to get out of unemployment quickly after this incident, as the benefits are likely to increase concerning older people with health restrictions. Finally, due to the Covid-19 pandemic, much attention has been paid to health issues. Even though the economy has recovered, it is advisable to offer more targeted projects for long-term unemployed people in the age group of $50+$. The aging of society continues in general.

It would be interesting to investigate further how the number of long-term unemployed persons aged 50+ in Austria will develop, mostly based on demographic characteristics, such as the differences between urban and rural areas. This research dealt with ESF implementing organizations' perspectives, including a case study that presented the project organization's view. For the future analysis, however, qualitative research based on interviews and questionnaires with the affected long-term unemployed persons aged 50+ and their perspectives would be interesting. 


\section{Limitations}

This paper refers exclusively to the ESF for the 2014 - 2020 programming period, focusing on long-term unemployment among persons aged 50+. It is generally considered from an Austrian perspective. From the European perspective, the regulations and guidelines for implementation in Austria are presented. It is not the aim of this paper to compare European countries or give project implementations on a purely national level. The objective of the national comparison is to provide general statistical data on long-term unemployment and to present ESF projects that also support the target group of long-term unemployed people in the age of $50+$.

\section{References}

Arbeitplus.at. (2020). Langzeitarbeitslosigkeit. Retrieved April 20, 2020, from https://arbeitplus.at/lexikon/langzeitarbeitslosigkeit/

Arbeitsmarktservice Österreich. (2020). Alter hat Zukunft Informationen für ältere Arbeitsuchende (45+). Retrieved April 26, 2021, from http://www.forschungsnetzwerk.at/downloadpub/AMS_Alter_hat_Zukunft_2020.pdf

Arbeitsmarktservice Österreich. (2020a). Fachbegriffe. Retrieved March 31, 2020, from https://www.ams.at/arbeitsmarktdaten-und-medien/arbeitsmarktdaten-und-arbeitsmarkt-forschung/fachbegriffe

Artis, M., \& Nixson, F. (2003). The Economics of the European Union (3 ed.). Great Britain: Oxford University Press.

Barnes, M., Heady, C., Middleton, S., Millar, J., Papadopoulos, F., Room, G., \& Tsakloglou, P. (2002). Poverty and Social Exclusion in Europe. Great Britain: Edward Elgar Publishing, Inc. https://doi.org/10.4337/9781781009710

Clemens, W. (2001). Ältere Arbeitnehmer im sozialen Wandel (Vol. 3). Opladen: Leske + Budrich. https://doi.org/10.1007/978-3-66309248-3

Clemens, W., Höpflinger, F., \& Winker, R. (2005). Arbeit in späteren Lebensphasen. Bern: Haupt Verlag.

Council of Europe. (1996). European Social Charter - European Treaty Series - No. 163. Retrieved November 10, 2019, from https://rm.coe. int/168007cf93\%20pp8

Council of Europe. (2010). Strengthening social cohesion - Improving the situation of low-income workers- Empowerment of people experiencing extreme poverty. Strasbourg: Council of Europe Publishing.

El-Agraa, A. M. (2011). The European Union: economics and policies. Cambridge: Cambridge University Press. https://doi.org/10.1017/ CB09780511844041

ESF Austria. (2019). Jährlicher Durchführungsbericht im Rahmen des Ziels "Investitionen in Wachstum und Beschäftigung". Wien: ESF Austria. Retrieved April 8, 2020, from https://www.esf.at/wp-content/uploads/2020/02/Implementation-report_2014AT05SFOP001_2018_1_de-SFC-Angenommen-Inhalt-Website.pdf

ESF Homepage Austria. (2017). ESF in Austria. Retrieved April 8, 2019, from https://www.esf.at/esf-in-oesterreich/

ESF Homepage Austria. (2017a). Schwerpunkte. Retrieved December 29, 2020, from https://www.esf.at/foerderprogramm/schwerpunkte/

European Commission. (2019). Report from the Commission to the Council on evaluating the Council Recommendation on integrating the long-term unemployed into the labor market. Retrieved April 8, 2020, from https://www.google.at/url?sa=t\&rct=j\&q=\&esrc=s\&source=web \&cd=1 \&ved=2ahUKEwjhovKQktvoAhVowosKHSTZDMYQFjAAegQIAxAB\&url=https\%3A\%2F\%2Fec.europa.eu\%2Fsocial\%2FBlobServlet\%3Fdocld\%3D21017\%26langld\%3Den\&usg=AOvVaw1_YBKzaX_ub7LrWAfbTQJk

Eurostat. (2019). People at risk of poverty or social exclusion. Retrieved May 3, 2019, from https://ec.europa.eu/eurostat/statisticsexplained/index.php/People_at_risk_of_poverty_or_social_exclusion\#Number_of_people_at_risk_of_poverty_or_social_exclusion

European Parliament (2021). Report on reducing inequalities with a special focus on in-work poverty. (2019/2188(INI)). Retrieved April 26, 2021, from https://www.europarl.europa.eu/doceo/document/A-9-2021-0006_EN.html

Eurostat, E. (2014). Eurostat regional yearbook 2014. DOI:10.2785/54659

Graf, N., Hofer, H., \& Winter-Ebmer, R. (2011). Labor supply effects of a subsidized old-age part-time scheme in Austria. (I. f-u. 2011, Ed.) ZAF; 229. https://doi.org/10.1007/s12651-011-0072-8

Gruber, E., Kastner, M., Brünner, A., Huss, S., \& Kölbl, K. (2007). Arbeitsleben 45 plus -Erfahrung, Wissen und Weiterbildung - Theorie trifft Praxis. Klagenfurt: Hermagoras/Mohorjeva družba.

Kaiser, R. (2014). Qualitative Experteninterviews: Konzeptionelle Grundlagen und praktische Durchführung. Wiesbaden: Springer VS.

Klinger, S., \& Rothe, T. (2010). Entwicklung der Langzeitarbeitslosigkeit in Aufschwung und Krise. Wirtschaftsdienst, 632-634. https://doi. org/10.1007/s10273-010-1128-z

Kuckartz, U. (2010). Einführung in die computergestützte Analyse qualitativer Daten (3. ed.). Wiesbaden:VS Verlag für Sozialwissenschaften. https://doi.org/10.1007/978-3-531-92126-6

Lobato, P. (2017). Geförderte Beschäftigung für Langzeitarbeitslose. Wiesbaden: Springer Fachmedien Wiesbaden GmbH. https://doi. org/10.1007/978-3-658-18228-1 
Lutz, H., \& Bock-Schappelwein, J. (2014). Ex-ante-Evaluierung des Operationellen Programms Beschäftigung: Österreich 2014-2020. Wien: ÖSTERREICHISCHES INSTITUT FÜR WIRTSCHAFTSFORSCHUNG. Retrieved April 8, 2020, from https://www.esf.at/wpcontent/ uploads/2017/06/ESF_exante_eval_30okt_final.pdf

Mathijsen, P. (2010). A Guide to European Union Law (10 ed.). Great Britain: Sweet and Maxwell.

MAXQDA - Produkte. (2020). MAXQDA Produkte. (MAXQDA - Vertrieb durch die VERBI GmbH) Retrieved March 24, 2020, from https://www. maxqda.de/produkte

Mayring, P. (2015). Qualitative Inhaltsanalyse - Grundlagen und Techniken (12. ed.). (W. u. Basel, Ed.) Deutschland: Beltz Verlag.

ÖROK. (2019). European Structural and Investment Funds in Austria 2014-2020. Retrieved April 10, 2019, from https://www.oerok.gv.at/ esi-fonds-at/

Patton, W., \& Donohue, R. (1998). Coping with long-term unemployment. Journal of Community \& Applied Social Psychology, 8, $331-343$. https://doi.org/10.1002/(SICI)1099-1298(1998090)8:5<331::AID-CASP456>3.0.CO;2-6

Prean, N., \& Mayr, K. (2016). Cyclical Unemployment Fluctuations of Immigrants and Natives: Evidence from Austria. CESifo Economic Studies, 1-25. https://doi.org/10.1093/cesifo/ifv013

Putz, S., Tamler, P., Haydn, F., Natter, E., \& Tauber, M. (2014). Altersspezifische Personalpolitik und der Beitrag des AMS. (A. Österreich, Ed.) Retrieved February 8, 2020, from http://www.forschungsnetzwerk.at/downloadpub/Endbericht_altersspezifische-Personalpolitik. pdf

Von Cranach, M., Schneider, H.-D., Ulich, E., \& Winkler, R. (2004). Ältere Menschen im Unternehmen. Bern: Haupt Verlag.

Westermeier, Christian (2019): Ältere am Arbeitsmarkt: Eine stabile Beschäftigung vor dem Rentenalter begünstigt die Weiterarbeit. (IAB-Kurzbericht, 15/2019), Nürnberg.

\section{Evropski socialni sklad podpira ponovno vključitev dolgotrajno brezposelnih posameznikov $\vee$ starostni skupini 50+ na trg dela - primerjava zveznih dežel v Avstriji}

\section{Izvleček}

Ta članek obravnava pomen Evropskega socialnega sklada (ESS) pri vključevanju naraščajočega števila dolgotrajno brezposelnih $\vee$ starostni skupini 50+ na trg dela v zadnjih letih v Avstriji. Zastavljena so štiri raziskovalna vprašanja, ki obravnavajo osnove in prispevek ESS, možne vzroke dolgotrajne brezposelnosti in njihov odraz $v$ številkah. $V$ okviru kvalitativne metodologije so bili opravljeni intervjuji s strokovnjaki in izvedena študija primera. V okviru kvantitativne metode so bili ovrednoteni neobdelani podatki Javnega zavoda za zaposlovanje (AMS Avstrija) in avstrijskega statističnega urada. Ugotovljena je bila povezava med vsebinskimi ocenami teoretičnih pristopov, strokovno analizo in statističnimi podatki. Za boj proti dolgotrajni brezposelnosti v tej ciljni skupini je treba pravočasno ugotoviti vzroke in sprejeti ustrezne ukrepe za njeno preprečevanje.

Ključne besede: trga dela, dolgotrajno brezposelni v starostni skupini 50+, Evropski socialni sklad, Avstrija 